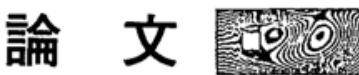

\section{建物頂部における風速特性変動に関する実験的研究 Wind tunnel study on the flow characteristics variation over a building}

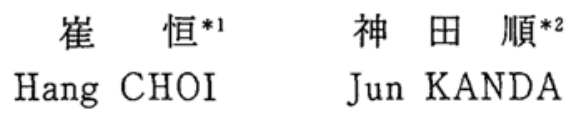

SUMMARY

One of the difficulties in full scale measurements in urban area exists in the installation of an anemometer at an appropriate position without any influences of the obstacles. In order to determine the appropriate measuring position above the building and to provide a basic reference of influence correction, wind tunnel studies were carried out for several building models which are considered as typical building shapes in urban area. As a result, variations of the mean wind velocity profile and turbulence intensity profile, and of the spectral density distributions are presented and discussed comparing with those of the original flow free from the obstacles.

1.はじめに

近年, 軽量構造材の発展と.共に建物の高層化が 進められ, 風荷重の考應が不可欠なものとなって きている。合理的な風荷重の評価のための自然風 観測の重要性が強調され，これまで様々な地形に 対する数多くの自然風観測が行われてきた。また，
これらの観測結果は数学的モデルの形で荷重評価 規準等に取り入れられているが，それらのほとん どが主に平坦地域で観測された結果に基づいたも のであるため実際に，市街地など具体的な特定の 地域に適用するにはその地域における観測記録を 用いて確かめる必要がある。しかし, 建物の頂部

*1 東京大学大学院生

Graduate student, University of Tokyo

$* 2$ 東京大学工学部, 助教授

Associate Professor, University of Tokyo

(平成元年 2 月 22 日受理，尌論期限：平成元年 7 月 31 日) 
を利用して観測が行われている市街地での場合, 風速計の取り付けられている建物や周辺の障害物 の影響を受けないような観測地点の設定が難しい ため観測事例が少なく, さらに観測地点の設定が 測定する側の経験的判断に大きく依存されている ため, 取られた記録の信頼性が問われることもし ばしばある1。一一方，障害物による流れの特性へ の影響に関してはいくつかの理論的または実験的 研究成果が報告されているものの，それらのほと んどが渦の形成発達等, 流体の動適メカニズム2)

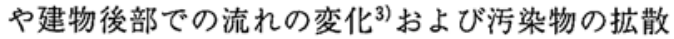
またはいわゆるビル風と言った環境的問題に関す るものであっで), 適切な観測地点の設定や記録 への影響等, 測定する側の苦情に関わりの大きい 建物頂部における流れ特性の変化に関してはあま り検討されておらず, 基本的資料の蓄積が要求さ れているのが現状である。

本論文においては市街地における建物の代表的 な形と思われる形状の模型に対する複数の条件で の風洞実験結果を基に, 観測された特性への建物 の影響及びその影響範囲に関して検討し，適切な 測定位置の設定に関する基本的な资料の提供を試 みる。

\section{2. 実験概要}

2. 1 模型の形状および寸法

実験に用いられた模型は正方形と長短比 2：1 の長方形断面を有するものである。正方形の場合 は 2 つの風向に対して実験を行い, 風向の違いに よる記録の統計的特性の変化について考察する。 一方, 長方形に対しては異なる 2 つ場所に塔屋 がある場合とない場合に対して検討を行った。模 型の形状および寸法をまとめてTable 1に示す。

\section{2 使用風洞および風洞気流}

実験は建設省建築研究所の乱流境界層風洞（測 定部の高さ2. $5 \mathrm{~m}$,幅 $3.0 \mathrm{~m}$ ，長さ $25.0 \mathrm{~m}$ ) で行った。 気流の作成に当たっては高さ約 $1.0 \mathrm{~m}$ の三角形スパ イヤーと $50 \times 50 \times 50 \mathrm{~mm}$ おび $30 \times 30 \times 30 \mathrm{~mm}$ の粗度 ブロックを用いた。作成された乱流境界層の高さ は約 $90 \mathrm{~cm}$ 程度で，平均風速の鉛直分布特性はべき 指数 0.23 のべき指数分布で表わされる。また,境界 層高さにおける平均風速は約 $8.4 \mathrm{~m} / \mathrm{s}$ であり, 模型 頂部高さでの乱れの強さは約10\%である。これら の値は高密度市街地を対象とする場合には若干小 さめであるが, 中小都市に対しては概ね適してい ると思われる。Fig. 1と2に作成気流の平均風速と

Table 1. 実験模型の形状と寸法

(Dimensions and shapes of building model)

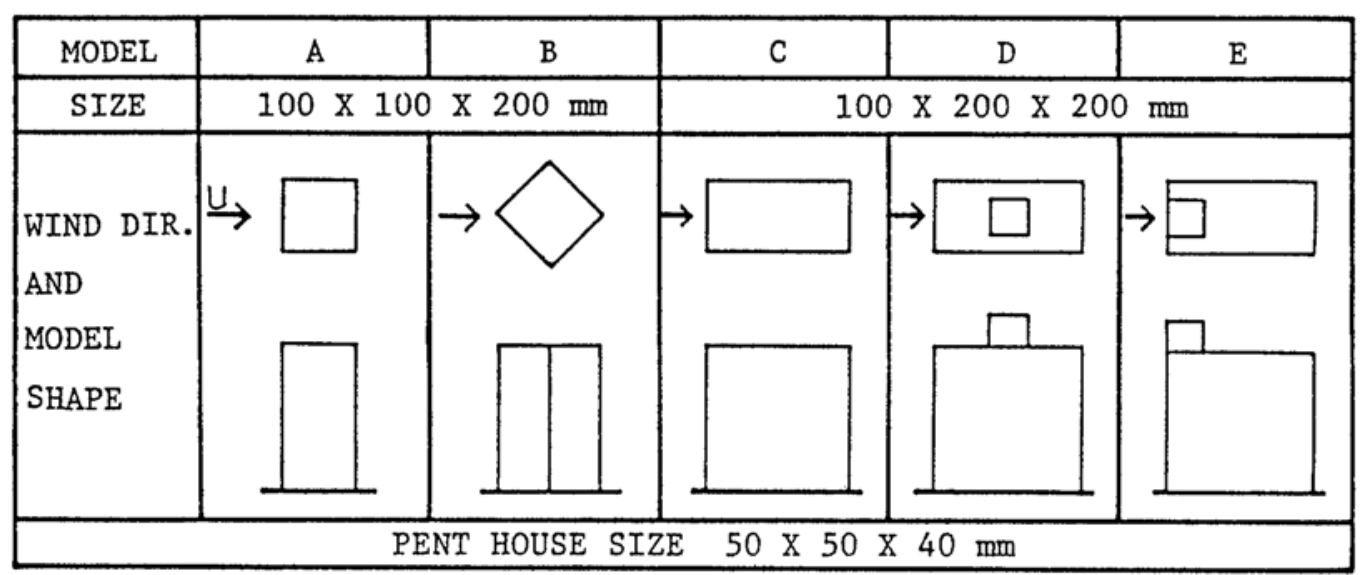




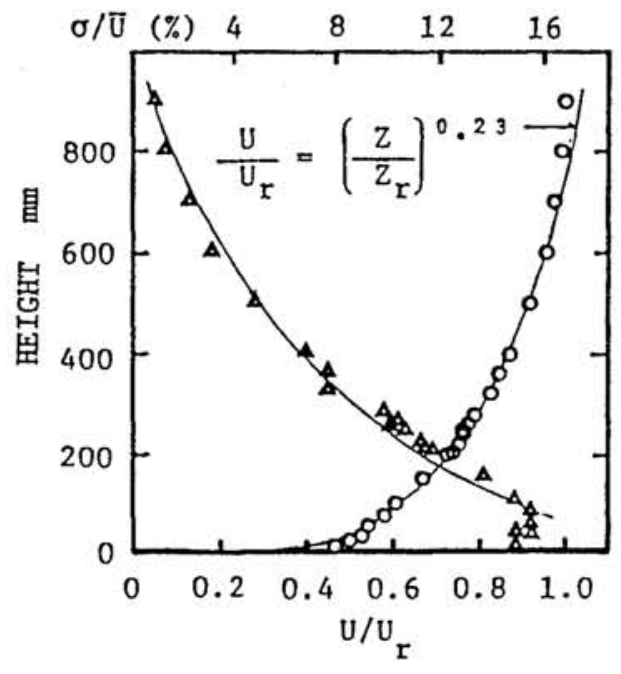

Fig. 1 平均風速と乱れの強さの鉛直分布 (Profiles of mean velocity and turbulence intensity)

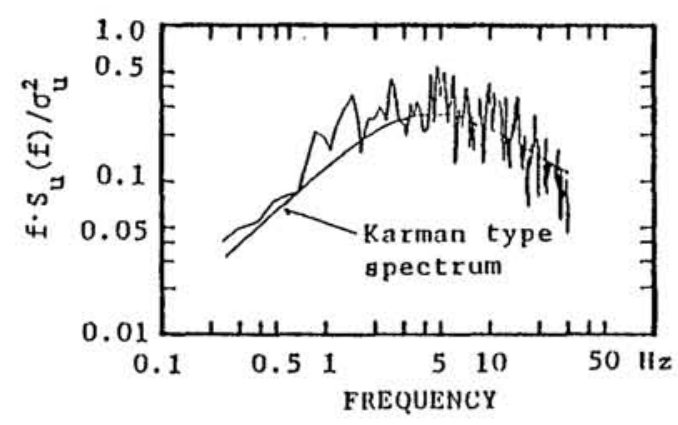

Fig. 2 風洞気流のパワースペクトル密度特性 (Power spectral density of simulated flow)

乱れの強さの鉛直分布および模型頂部高さにおけ る変動風速のパワースペクトル密度分布を示す。

\section{3 測定点と測定データの概要}

変動風速の測定に当たっては I 型熱線風速計を 用いて行われた。風速計からの電圧信号はパソコ ンによって制御される $\mathrm{A} / \mathrm{D}$ 変換器を介して60秒 単位に測定されており，変換器におけるサンプリ ング周波数は $100 \mathrm{~Hz}$ である。次に，模型頂部にお ける変動風速の測定点の数はCASE A,Bの場合それ
ぞれ15点と18点であり，C,D,Eの場合は9,12,18点 ずつである。また, 高さ方向の影響範囲を調べる

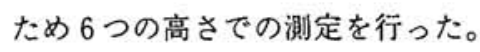

\section{3. 実験結果}

\section{1 解析方法}

障害物の影響による流れ特性の変化は一般的に （1）平均風速の增減，(2)乱れの強さの增減，およ び(3) 変動風速のパワースペクトル密度分布の変 化によって特徵付けられよう。それゆえ，実験結 果の解析において, 平均風速と乱れの強さの場合 は式(1)と (2)で表わされる模型のない場合の特性 に対する相対的変化をもって検討した。また，式 における添字0はFig.3に示すように模型のない場 合の特性を表す。

$$
\begin{aligned}
& \Delta_{u}=\frac{U(z)-U_{0}(z)}{U_{0}(z)} \\
& \Delta_{i}=\frac{\sigma(z)}{U(z)}-\frac{\sigma_{0}(z)}{U_{0}(z)}
\end{aligned}
$$

一方，スペクトル特性の変化に関してはパワース ペクトル密度関数が単位面積を有する場合, 即ち 分散で除して基準化してある場合は一般的な確率 密度関数として取り扱えるので式 (3),(4)，(5)で

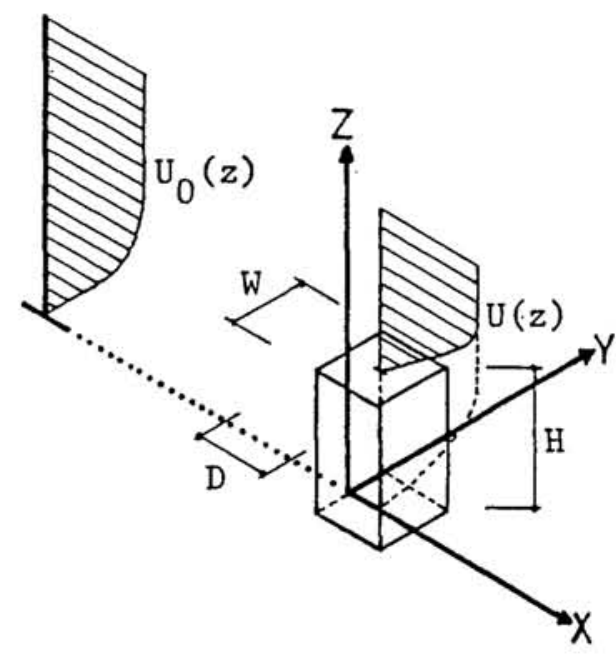

Fig. 3 座標系および記号

(Coordinate system and nomenclature) 
定義される周波数の中央値, 平均值, および標準 偏差を用いることが有効であり ${ }^{5)}$, 平均値と標準 偏差の相対的変化を調べるには式 $(7),(8)$ を用い た。

$$
f_{\mathrm{m}}=F_{\mathrm{s}}^{-1}(0.5)
$$

ここで,

$$
F_{s}\left(f_{i}\right)=\int_{0}^{f_{i} \tilde{S}_{\mathrm{u}}(f) d f}
$$$$
\tilde{S}_{\mathrm{u}}(f): \text { 規準化パワースペクトル }
$$

$$
\begin{aligned}
& \Omega_{1}=\frac{\int_{0}^{f_{c}}{ }_{f} S_{u}(f) d f}{\int_{0}^{f_{c}} S_{u}(f) d f} \\
& \Omega_{3}=\sqrt{\Omega_{2}{ }^{2}-\Omega_{1}{ }^{2}}
\end{aligned}
$$

ここで，f $\mathrm{f}$ はローパスフィルターにおける遮断 周波数であり， $\Omega_{2}$ は次式で定義される。

$$
\begin{aligned}
& \Omega_{2}=\left(\frac{\int_{0}^{f_{c} f^{2} \cdot S_{u}(f) d f}}{\int_{c}^{f_{c}} S_{u}(f) d f}\right)^{1 / 2} \ldots \ldots \\
& \Delta_{\Omega_{1}}=\frac{\Omega_{1}-\Omega_{1}^{0}}{\Omega_{1}^{0}} \\
& \Delta_{\Omega_{3}}=\frac{\Omega_{3}-\Omega_{3}^{0}}{\Omega_{3}^{0}}
\end{aligned}
$$

\section{1 平均風速の変化}

模型頂部における $\mathrm{Y}, \mathrm{Z}$ 方向の平均風速の変化 に関する代表例をFig. 4に示す。図におけるOは 式（1）で定義される模型のないときの平均風速に 対する相対的増減を表す。 Z方向の変化に関して は風向が模型面に対して直角であるCASE Aの場合, 模型による影響範囲が最も高く, 相対的増減が 10 \%以下になるまでにはかなりの高さが必要とされ る。一方, 風向が模型面に対して $45^{\circ}$ であるCASE
Bの場合は影響範囲がCASE Aと比較してかなり低 く,ほとんどの測定点で10\%以下の相対的増減を 示している。また, CASE Aにおいて, 最も大きい 平均風速の加速はスパン中心上の約スパン半分の 高さを通る放物線上に認められ，その大きさは20 \%前後である。このような傾向はCASE C, D ,Eにお いても同様である。次に，Y方向の変化について は模型中心から離れて行くほど相対的変化が小さ くなり, 平均風速の最大加速値が現れる高さも低 くなる。

\section{2 乱れの強さの変化}

乱れの強さに対する $\mathrm{Y}, Z$ 方向の変化の一例を Fig.4に示す。図におけるのは式 (2)で定義される相 対的増減を表す。模型によるZ方向の影響範囲の 変化に対する一般的傾向は平均風速に対するもの と同様であるが, 平均風速の最大加速が現れる高 さ以上での変化はほとんど認められず, CASE A,C, $\mathrm{D}, \mathrm{E}$ における剥離領域では乱れの強さの増加が 40 \%に達している。しかし，CASE Bの場合すべての 観測点での変化は $5 \%$ 以下であり, 平均風速の場 合と同じく模型による影響は少ない。一方，Y方 向に対する変化の一般的傾向は平均風速の場合と 同様である。

\section{3 スペクトルの統計的特性值の変化}

模型による変動風速のパワースペクトル密度分 布および周波数の中央值に関する変化の一例をス ペクトルの累積分布関数を用いてFig. 5に示す。 図において, 波線は模型のないときのスペクトル の累積分布関数と周波数の中央値を表す。結果に おいて, 低い測定点では模型の影響のない場合と 比較して中央值がかなり大きくなっており，高さ が高くなるにつれてその違いは小さくなる。また， 平均風速の増加が10\%以下の高さにおいては中央 値の違いが若干見られるものの, 累積分布関数の 形状はほぼ一致する。参考としてFig. 6に異なる 

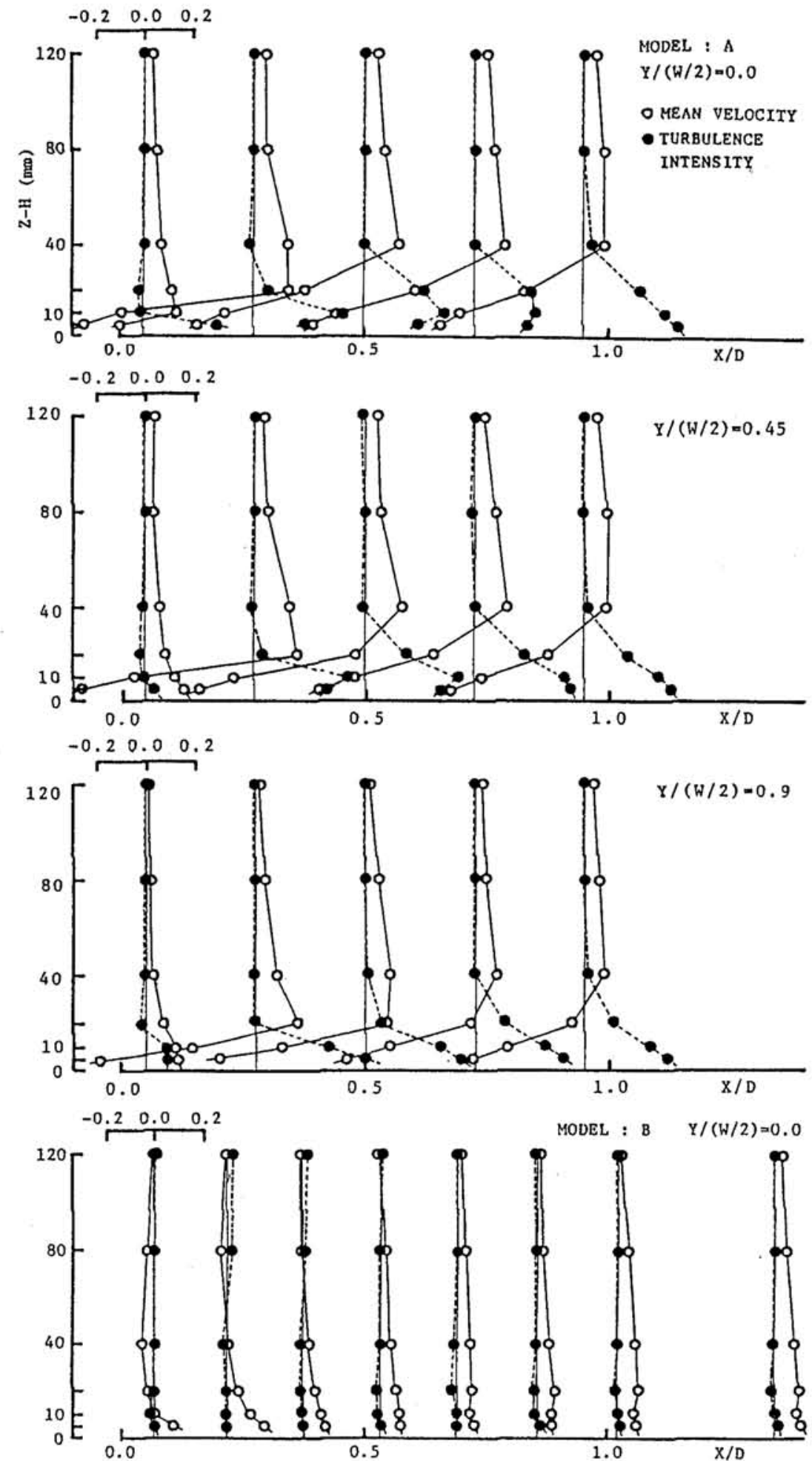

Fig. 4 平均風速と乱れの強さの変化

(Mean velocity and turbulence intensity variations) 

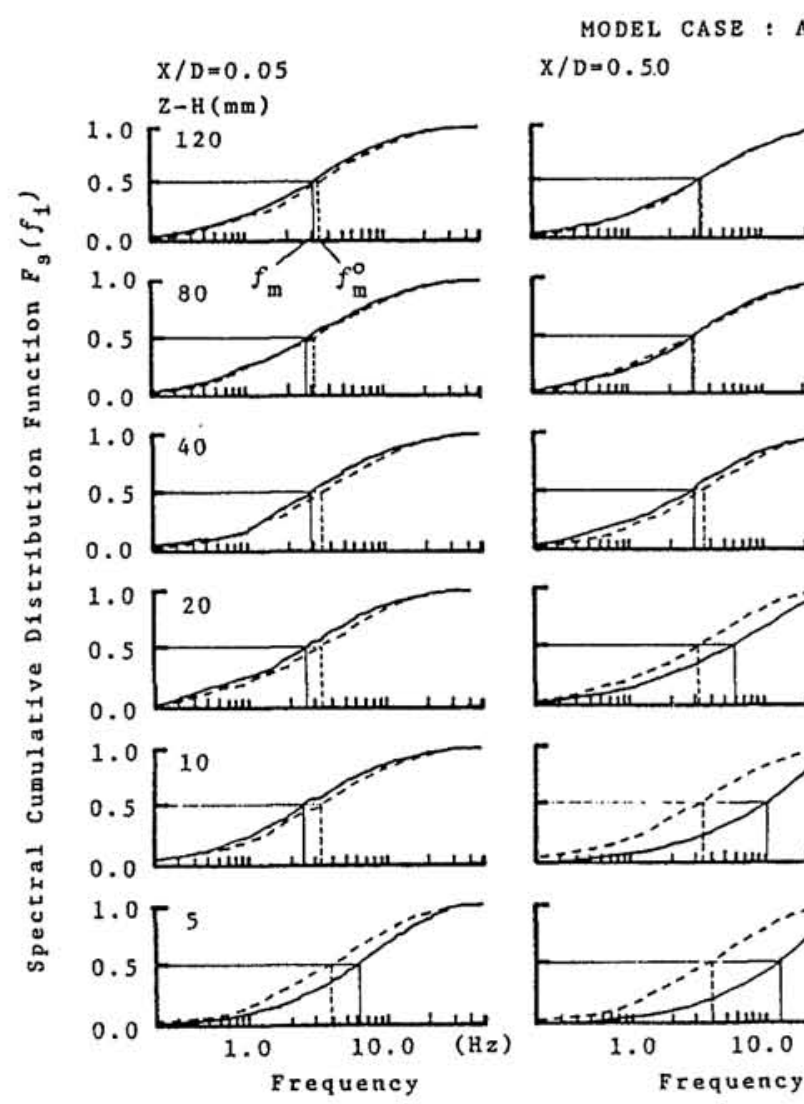

$X / D=0.90$
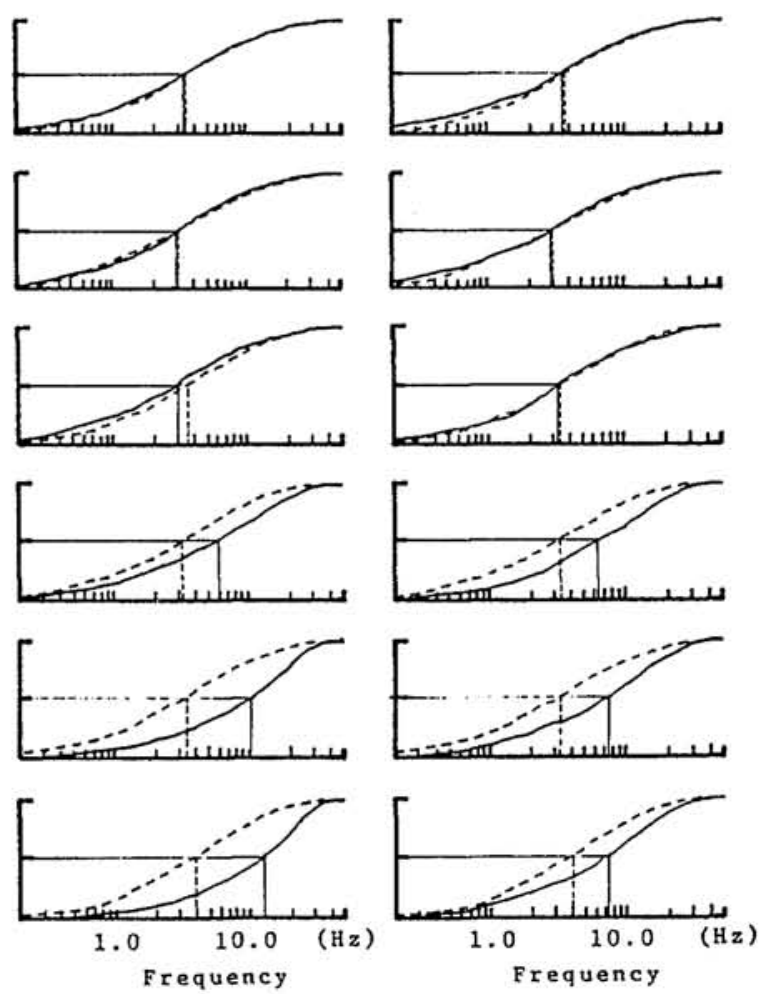

Fig. 5 スペクトルの累積分布関数および周波数の中央値の変化

(Variations of spectral cumulative distribution functions and median frequencies)

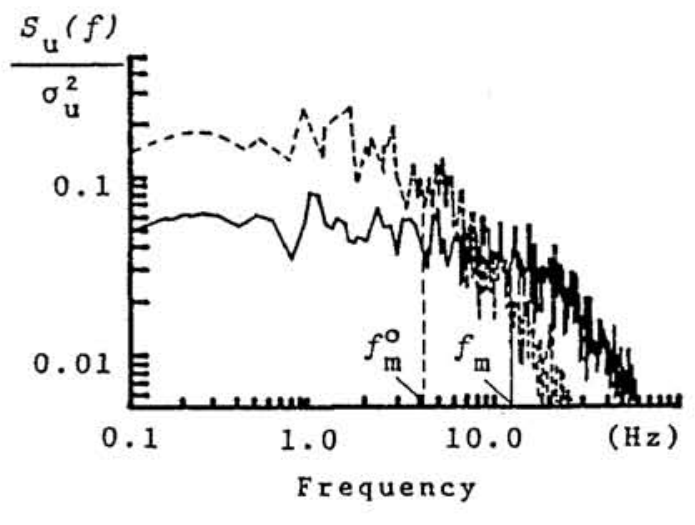

Fig. 6 異なる周波数の中央值に対するパワースペ クトル密度関数

(Comparison between power spectral density distributions with different median frequencies)
中央值に対するパワースペクトル密度分布関数の 一例を示す。一方，式(4)，（5)で定義される周波 数の平均值および標準偏差の変化を調べ, それら の結果をFig. 7に示す。結果から，式(7)，(8)で 定㼁される $\Omega_{1}$ と $\Omega_{3}$ の変化傾向は互いに似ており， 特に周波数の標準偏差に関する変化傾向は乱れの 強さに対するものとほぼ一致する。また, CASE B に対する統計的特性値それぞれの変化については Fig. 4に示した平均風速, 乱れの強さの場合と同 しく大きな変化は認められない。

\section{4. まとめ}

実験結果のまとめとして次の $5 つ$ の值による境 界線を示すことができる。 

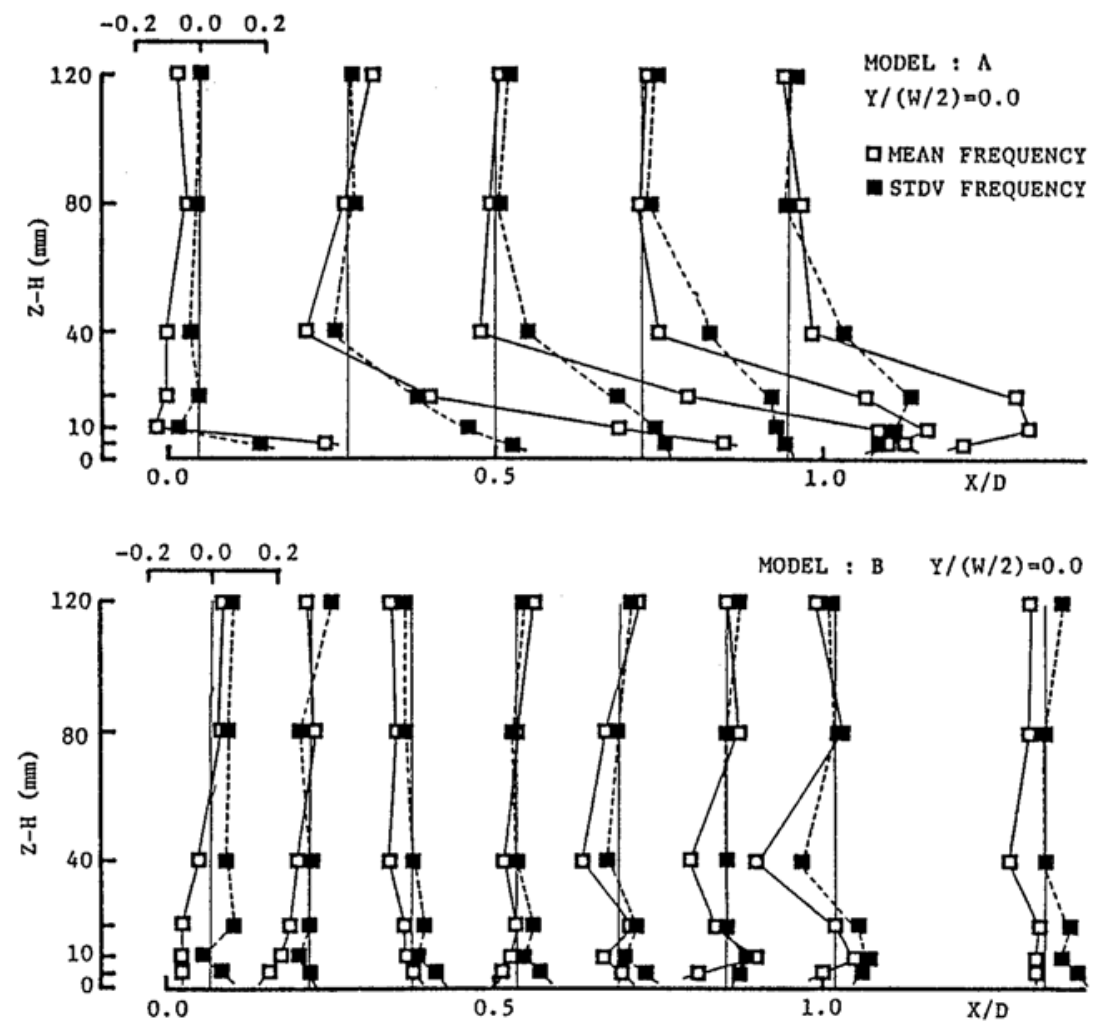

Fig. 7 周波数の平均値と標準偏差の変化

(Variations of the mean and standard deviation frequency)

(1) 平均風速の増加と減少との境界線 $(\Delta u=0)$

(2)平均風速に対する相対的変化の絶対值が $10 \%$ 以下になる境界線 $(\Delta \mathrm{u}= \pm 10 \%)$

(3)乱れの強さに対する相対的変化が5\%以下にな る境界線 $(\triangle \mathrm{i}=5 \%)$

(4) 周波数の平均値に対する相対的变化が $20 \%$ 以 下になる境界線 $\left(\Delta \Omega_{1}=20 \%\right)$

(5)周波数の標準偏差に対する相対的変化が $20 \%$ 以下になる境界線 $\left(\Delta \Omega_{3}=20 \%\right)$

5 つの実験モデルに対するこれらの境界線それ ぞれをFig. 8〜12に示す。Fig. 8における境界線は Fig. 11,12から予想できるような広帯域スペクト ル特性をもつ高周波変動成分によって乱れの強さ がかなり增加する剥離領域との境界を表している と思われる。一方, 平均風速はFig. 9 で示した境
界線の上部領域において加速されることがあるが, その時Fig. 8で示した境界線の上部領域における 乱流特性の変化は少ない。更に, Fig.8とFig.9を 比較するに当たって後者における境界線の高さが 前者のそのものより低い場合, Fig. 9における境 界線はー10\%を指すことに注意されたい。

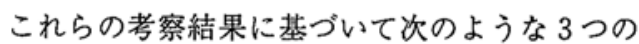
領域が考えられる。

(I) 剝離領域一この領域における観測記録の信頼 性は保証し難い。

（II）加速領域一この領域は信頼性のある記録を得 るには適していないが, 今回の風洞実験結果を参 考にしての修正は可能である。

(III) 推奖領域一この領域における平均風速の增減 は10\%以下であり, 変動風速のスペクトル特性の 


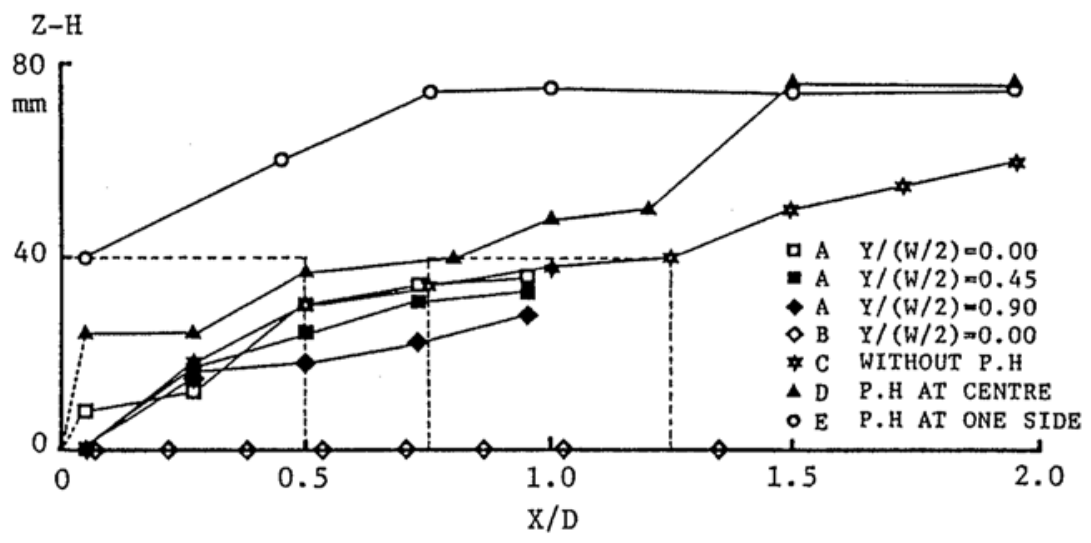

Fig. 8 各模型に対する平均風速増減の境界

(Boundary between mean velocity increasing and decreasing zone)

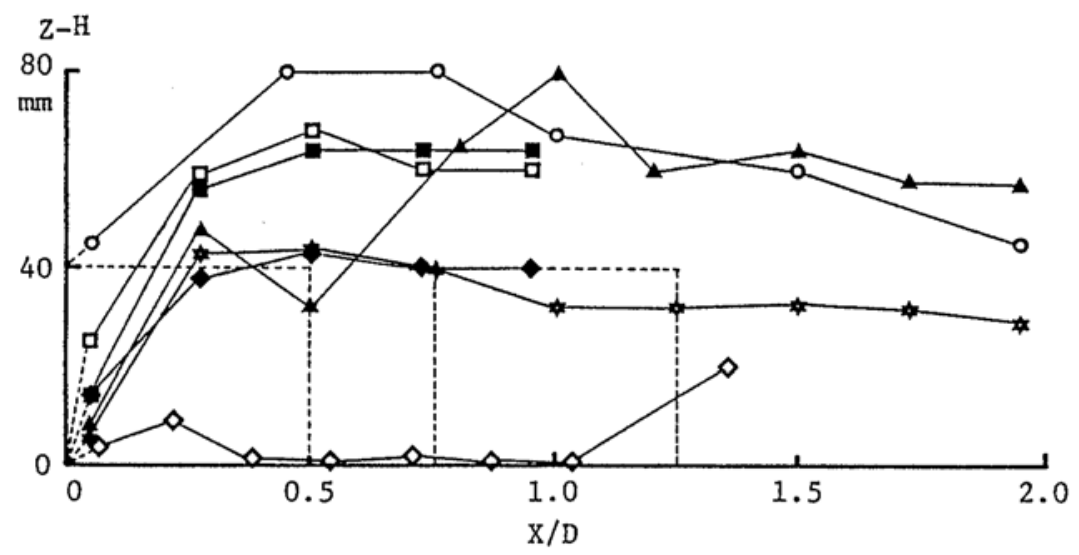

Fig. 9 平均風速の $\pm 10 \%$ 変動に対する境界

( $\pm 10 \%$ variation boundary of mean velocity)

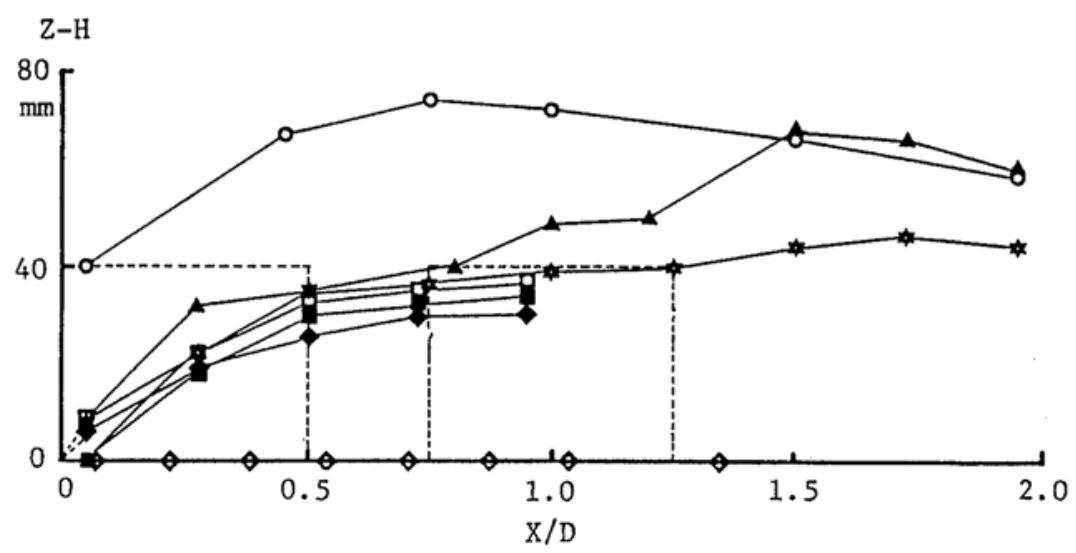

Fig. 10 乱れの強さの $5 \%$ 増加に対する境界

(Boundary for $5 \%$ increase of turbulence intensity) 


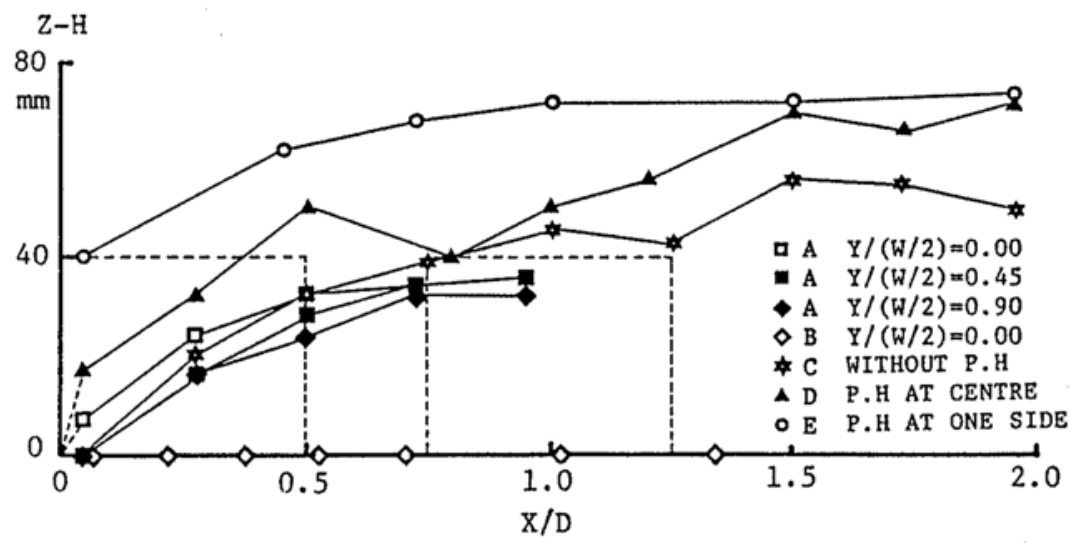

Fig. 11 周波数の平均値の $20 \%$ 増加に対する境界

(Boundary for 20\% increase of mean frequency)

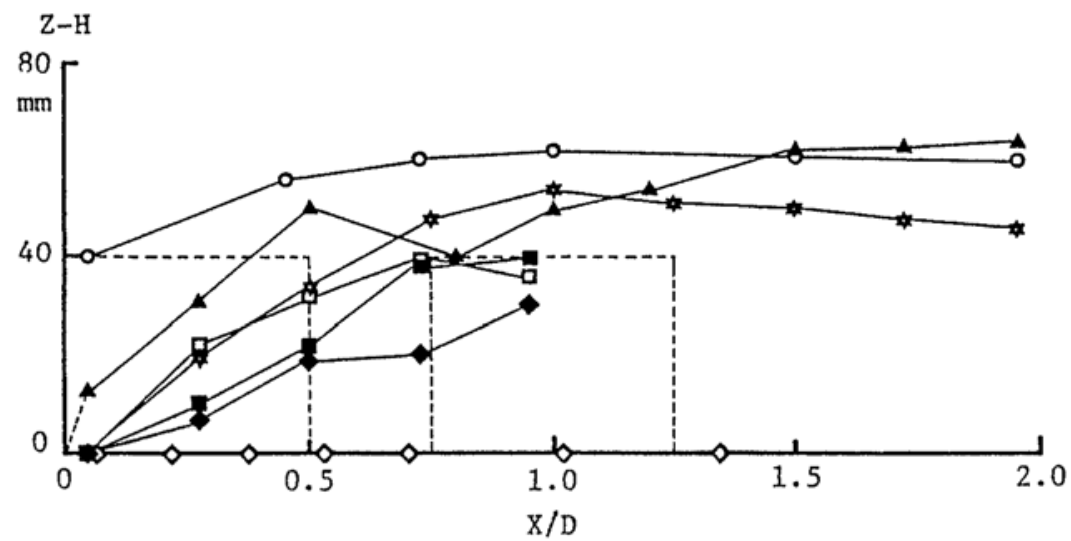

Fig. 12 周波数の標準偏差の20\%増加に対する境界

(Boundary for $20 \%$ increase of standard deviation frequency)

\section{変化はほとんどない。}

領域 I と II との概略的な境界はFig8に示した境 界線に相当し, 領域 II と回との境界はFig. 9に示 したものに相当すると思われる。また，風速計を 設置するに当たっては塔屋を十分活用することが 望ましいが，塔屋が屋上の中央に位置している場 合はFig.9から予測されるように平均風速が大き く変動することがあり, 平均風速の評価のために は何らかの修正を行わなければならない。

今回の風洞実験による結果は限られた状況で得 られたものではあるが, 市街地での観測を行う際,
適切な測定位置の設定および測定記録の修正に基 本的な資料として活用できると思われる。

\section{謝 辞}

本研究を実施するに当たり，建設省建築研究所 の岡田恒博士より多大なる御協力を頂いた。また, 実験の実行に際しては東京大学大学院生小林創氏 に御協力を頂いた。ここに記して深く感謝の意を 表す。 


\section{参考文献}

1)崔 恒, 神田順『高密度市街地における平均風 速鉛直分布に関する予備的検討」日本建築学会 学術講演梗概集, 昭和 61 年, pp65 66

2) J. C. R. Hunt, C. J. Abell, J. A. Peterka, H. G. C. Woo "Kinematical studies of the flow around or surface-mounted obstacles : applying topology to flow visualization" Journal of Fluid Mechanics, 86, 1978,pp179 200
3) J. A. Peterka, R. N. Meroney, K. M. Kothari" Wind flow patterns about buildings "Journal of Wind Eng. and Industrial Aerody. ,21,1985,pp $21 \sim 38$

4) N. Isyumov, A. G. Davenport "The ground level wind environment in built-up areas "Proc. 4th ICWE, Cambridge University Press,1977, pp 403 421

5)E. Vanmarcke"Random Fields-Analysis and Synthesis" MIT Press, 1984, pp138 183 